\title{
Asymbiotic Seed Germination, Induction of Calli and Protocorm-like Bodies, and In Vitro Seedling Development of the Rare and Endangered Nothodoritis zhejiangensis Chinese Orchid
}

\author{
Song-jun Zeng ${ }^{1}$ \\ Key Laboratory of Plant Resources Conservation and Sustainable Utilization, \\ South China Botanical Garden, The Chinese Academy of Sciences, Guangzhou \\ 510650, China; and Graduate University of Chinese Academy of Sciences, \\ Beijing 100039, China \\ Zhi-lin Chen \\ Horticultural Research Institute of Guizhou Province, Guiyang 550006, \\ China
}

Kun-lin Wu and Jian-xia Zhang

Key Laboratory of Plant Resources Conservation and Sustainable Utilization, South China Botanical Garden, The Chinese Academy of Sciences, Guangzhou 510650, China

Cheng-ke Bai

College of Life Science, Shaanxi Normal University, Xian 726200, China

Jaime A. Teixeira da Silva

Faculty of Agriculture and Graduate School of Agriculture, Kagawa University, Miki-cho, Kagawa 761-0795, Japan

\section{Jun Duan}

Key Laboratory of Plant Resources Conservation and Sustainable Utilization, South China Botanical Garden, The Chinese Academy of Sciences, Guangzhou 510650, China

\section{Additional index words. coconut water, organic supplement, acclimatization}

\begin{abstract}
Nothodoritis zhejiangensis Z. H. Tsi is a rare and endangered epiphytic orchid restricted to a narrow distribution in China. The species is threatened with extinction as a result of loss of suitable habitats. An efficient propagation system is part of this species' conservation plan. Seed germination reached $64.7 \%$ on Knudson's C (KC) medium containing $1.0 \mathrm{mg} \cdot \mathrm{L}^{-1} \alpha$-naphthaleneacetic acid (NAA), $10 \%$ coconut water, and $0.1 \%$ activated charcoal. After 50 days culture, most callus (71.3\%) from seed-derived protocorms formed on $\mathrm{KC}$ medium with $1.0 \mathrm{mg} \cdot \mathrm{L}^{-1} 2$,4-dichlorophenoxyacetic acid and $10 \%$ coconut water. Callus could be subcultured 12 times during $\approx 2$ years with more than a 3.0 -fold increase from the third to the twelfth subculture. Furthermore, $84 \%$ of callus from the tenth sub-culture on KC media supplemented with $1.0 \mathrm{mg} \cdot \mathrm{L}^{-1} \mathrm{NAA}, 5 \%$ coconut water, and $0.1 \%$ activated charcoal formed protocorm-like bodies (PLBs). Many (57\%) protocorms on KC medium containing $1.0 \mathrm{mg} \cdot \mathrm{L}^{-1}$ 6-benzylaminopurine and $10 \%$ coconut water formed PLBs. Both callus and PLBs formed simultaneously from different protocorms on $\mathrm{KC}$ medium containing 0.01 to $1.0 \mathrm{mg} \cdot \mathrm{L}^{-1}$ thidiazuron and $10 \%$ coconut water. PLBs were incubated 12 times during $\approx 2$ years with an approximate $2.4-$ fold increase per sub-culture. Both callus and PLBs maintained their competence to regenerate plantlets. Hyponex N026 medium supplemented with $1.0 \mathrm{mg} \cdot \mathrm{L}^{-1} \mathrm{NAA}, 50 \mathrm{~g} \cdot \mathrm{L}^{-1}$ banana homogenate, and $0.1 \%$ activated charcoal was suitable for plantlet formation and growth of $95.5 \%$ of plantlets that developed from PLBs. The roots of plantlets $2 \mathrm{~cm}$ in height or taller were wrapped in Chilean sphagnum moss and fixed to a fir bark block; $69.3 \%$ of plantlets survived after 180 days in a greenhouse. This protocol is an efficient means for the large-scale propagation of this endangered orchid.
\end{abstract}

The only member of the monospecific genus Nothodoritis Z. H. Tsi, which belongs to the Orchidaceae family, is Nothodoritis zhejiangensis Z. H. Tsi. It has a narrow geographic distribution: the districts of Linan and Ningbo (Zhejiang Province), Kuangxian
(Guansu Province), and Zhengping (Shaanxi Province) in China (Shi et al., 2008; Tsi, 1989, 1999; Wu et al., 2009). The genus is locally known as "elephant nose orchid" because of its long, slender rostellum (Fu and Hong, 2002). N. zhejiangensis has a similar morphology to Doritis Lindl. and Phalaenopsis lowii Rich. f. (Christenson, 2001; Tsi, 1999). Its quite peculiar flowers are white with purple transverse bands on sepals and petals and with purple lip markings (Fig. 1A; Fu and Hong, 2002; Wu et al., 2009). It was first found on Xitianmu Mountain, Linan, Zhejiang Province, in 1970 and was named in 1989 (Tsi, 1989). N. zhejiangensis is a typical epiphytic orchid that grows on tree branches in forests or at forest margins at elevations of 300 to $900 \mathrm{~m}$ (Wu et al., 2009). It usually blooms in the summer and its florescence can last several weeks. This species has great horticultural value as an ornamental plant because of its flower color and shape.

$N$. zhejiangensis is threatened with extinction as a result of loss of suitable habitats (Zeng, 2009). To preserve and use this rare and endangered endemic orchid, it is necessary to establish an efficient propagation system for large-scale propagation to meet the demands of the horticultural trade and hobbyists without further damage to natural populations. Under natural conditions, the main means of propagation of $N$. zhejiangensis is sexual reproduction, although seeds germinate slowly and inefficiently as a result of the absence of an endosperm. In addition, germination usually requires symbiotic fungi (Zeng, 2009).

An in vitro seed germination protocol has been described for Doritis (Wu et al., 2005), whereas for Phalaenopsis, many protocols for in vitro propagation have been described that involve in vitro seed germination (Qiu et al., 2009), PLB formation from flower stalk buds (Tokuhara and Mii, 1993), callus induction, and subsequent somatic embryogenesis from leaves (Chen and Chang, 2006; Ishii et al., 1998). A detailed review on in vitro orchid seed germination was provided by Kauth et al. (2008). However, to date, no efforts have been made to develop a protocol for the in vitro propagation or conservation of $N$. zhejiangensis. The goal of this study was to establish an effective propagation system for the large-scale propagation of this endangered orchid.

\section{Materials and Methods}

Seed source and sterilization. Thirty naturally pollinated mature seed capsules of $N$. zhejiangensis from 10 plants, which were yellow-green and $\approx 4 \mathrm{~cm}$ in length, were collected from Tianmu Mountain, Linan, Zhejiang Province, China, in Aug. 2006. The capsules were surface-sterilized by rubbing with $70 \%(\mathrm{v} / \mathrm{v})$ ethanol for 3 to $5 \mathrm{~s}$ followed by agitation for $15 \mathrm{~min}$ in a solution containing $2 \%(\mathrm{v} / \mathrm{v})$ sodium hypochlorite and $0.05 \%(\mathrm{v} / \mathrm{v})$ Tween 20 . The capsules were then rinsed five times with sterile distilled water. 

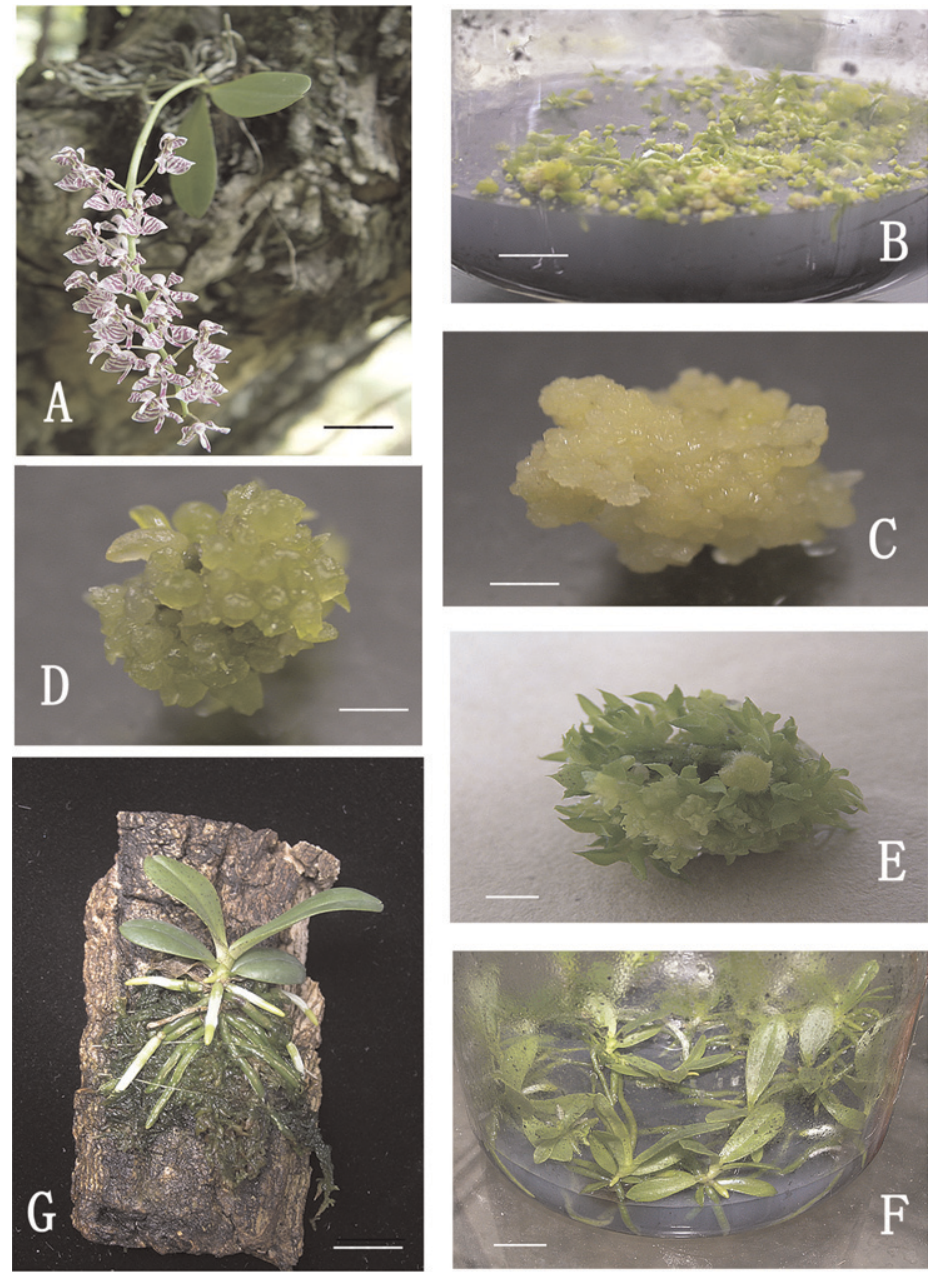

Fig. 1. Asymbiotic seed germination and in vitro seedling development of Nothodoritis zhejiangensis. (A) Flowering specimen of $N$. zhejiangens growing on the tree branches of Cornus officinalis. (B) Seed germination and protocorm development in vitro. (C) Yellowish callus mass developed from a protocorm. (D) PLBs developed from a callus mass. (E) Combination of shoot clusters, calli, and PLBs. (F) PLB-derived seedlings. (G) Transplanted seedlings on bark after growing in the greenhouse for 6 months. Bar is $2 \mathrm{~cm}(\mathbf{A})$ or $1 \mathrm{~cm}(\mathbf{B}-\mathbf{G})$. PLBs = protocorm-like bodies.

Asymbiotic seed germination and culture conditions. Approximately 200 seeds from each capsule were subjected to a tetrazolium (TZ) viability test (Lakon, 1949). To determine the influence of basal medium on seed germination, the disinfected capsules were cut open vertically with a sterile scalpel, and the seeds were placed on five basal sowing media without plant growth regulators: Murashige and Skoog (MS) (Murashige and Skoog, 1962), half-strength MS (half-strength MS macro- and micronutrients), KC (Knudson, 1946), Vacin and Went (VW; Vacin and Went,

Received for publication 12 Aug. 2010. Accepted for publication 28 Dec. 2010.

This study was supported by the National Key Project of Scientific and Technical Supporting Programs funded by the Ministry of Science \& Technology of China (No. 2008BAC39B05) and by Guangdong Key Technology Research and Development Programs (No. 2009B020201009; 2010B060200037).

${ }^{1}$ To whom reprint requests should be addressed; e-mailduanj@scib.ac.cn.
1949), and orchid seed sowing medium, Hyponex N026. This latter medium consisted of $1 \mathrm{~g} \cdot \mathrm{L}^{-1}$ Hyponex 1 (Taihe Horticultural Co. Ltd., Taiwan, China), $1 \mathrm{~g} \cdot \mathrm{L}^{-1}$ Hyponex 2, 100 $\mathrm{mg} \cdot \mathrm{L}^{-1}$ myo-inositol, $2 \mathrm{~g} \cdot \mathrm{L}^{-1}$ peptone, $1 \mathrm{~g} \cdot \mathrm{L}^{-1}$ niacin, $1 \mathrm{~g} \cdot \mathrm{L}^{-1}$ pyridoxine $\mathrm{HCl}$, and $1 \mathrm{~g} \cdot \mathrm{L}^{-1}$ thiamine $\mathrm{HCl}$. NAA, coconut water $(\mathrm{CW})$, and activated charcoal (AC) were added to media to improve orchid seed germination (Harvais, 1973; Hong et al., 2008; Rubluo et al., 1989). After initial trials, $\mathrm{KC}$ medium was shown to be the most appropriate basal medium for seed germination of $N$. zhejiangensis. Thus, $\mathrm{KC}$ medium containing NAA $(0.5,1.0$, or 2.0 $\left.\mathrm{mg} \cdot \mathrm{L}^{-1}\right), \mathrm{CW}(5 \%, 10 \%$, or $20 \%)$, and $\mathrm{AC}$ $(0.05 \%, 0.1 \%$, or $0.2 \%)$ were tested for improving seed germination. NAA and all plant growth regulators were purchased from Sigma Chemical Co. All media were supplemented with $30 \mathrm{~g} \cdot \mathrm{L}^{-1}$ sucrose and $6 \mathrm{~g} \cdot \mathrm{L}^{-1}$ agar. The $\mathrm{CW}$ used in these experiments was obtained from 6- to 7-month-old green coconuts from Hainan Province, China. The water was filtered through a single sheet of filter paper. The $\mathrm{pH}$ value of all media was adjusted to 5.8 with $1 \mathrm{~N} \mathrm{KOH}$ or $1 \mathrm{~N} \mathrm{HCl}$ before autoclaving at
$121{ }^{\circ} \mathrm{C}$ for $18 \mathrm{~min}$. For every treatment, $\approx 100$ seeds were cultured in a 250 -mL flat-bottomed culture flask containing $90 \mathrm{~mL}$ of medium. All experiments contained three independent replicates with 10 culture flasks per replicate. All cultures were incubated in a growth chamber at $25 \pm 2{ }^{\circ} \mathrm{C}$ under a 16 -h photoperiod provided by cool-white fluorescent lamps with a light intensity of 30 to $40 \mu \mathrm{mol} \cdot \mathrm{m}^{-2} \cdot \mathrm{s}^{-1}$. Seed germination was estimated for each treatment by three parameters: the time required for germination, germination percentage of seeds, and whether viable embryos from seeds were round or ovoid hyaline. The former two parameters were recorded after $60 \mathrm{~d}$ of culture. The seed germination percentage was calculated as the number of germinated seeds out of the total number of cultured seeds in a flask.

Induction of callus and protocorm-like bodies from protocorms. Callus and PLB induction, development, and subculture from seed-derived protocorms were studied as possible methods for the large-scale propagation of $N$. zhejiangensis. Seed-derived protocorms were cultured on $\mathrm{KC}$ medium for inducing callus or PLBs by supplementing the medium with $10 \% \mathrm{CW}$ and thidiazuron (TDZ) at 0.01 , $0.1,0.5$, or $1.0 \mathrm{mg} \cdot \mathrm{L}^{-1}, 6$-benzylaminopurine (BAP) at $0.1,0.5,1.0$, or $2.0 \mathrm{mg} \cdot \mathrm{L}^{-1}$, or 2,4 dichlorophenoxyacetic acid (2,4-D) at $0.1,0.5$, 1.0 , or $2.0 \mathrm{mg} \cdot \mathrm{L}^{-1}$ singly and some in combinations. The percentage of plantlets that formed, the amount of callus or number of PLBs that were induced, and the number of unresponsive or dead protocorms were calculated after $50 \mathrm{~d}$ of culture. Twenty protocorms were cultured per flask, and each experiment was repeated three times with 10 culture flasks per treatment.

Subculture of callus and protocorm-like body formation from callus. Callus from protocorms were subcultured every $50 \mathrm{~d}$ on $\mathrm{KC}$ medium supplemented with $10 \% \mathrm{CW}$ and 1.0 $\mathrm{mg} \cdot \mathrm{L}^{-1} 2,4-\mathrm{D}$ to proliferate callus. Twelve subcultures were performed within a period of $\approx 2$ years. Callus proliferation frequency was calculated as the ratio of the fresh weight of newly formed callus compared with incubated callus; fresh callus was weighed on sterile filter paper in a laminar flow cabinet to maintain sterile conditions. PLBs were induced to form callus on $\mathrm{KC}$ medium supplemented with $0.1 \%$ $\mathrm{AC}, 5 \% \mathrm{CW}$, and NAA at $0.1,0.5,1.0$, or $2.0 \mathrm{mg} \cdot \mathrm{L}^{-1}$. Twenty callus clumps $(\approx 2.0 \mathrm{~g}$ each, fresh weight) were cultured per flask, and each experiment consisted of three independent replicates with 10 culture flasks per replicate.

Protocorm-like body proliferation. PLBs were proliferated on $\mathrm{KC}$ medium supplemented with $10 \% \mathrm{CW}$ and $1.0 \mathrm{mg} \cdot \mathrm{L}^{-1} \mathrm{BAP}$ at 50-d intervals for each subculture. Twelve subcultures were performed during $\approx 2$ years. PLB proliferation efficiency was calculated as the ratio of the number of PLB numbers newly formed compared with incubated PLBs. Twenty PLBs (1.5 $\mathrm{mm}$ in diameter) were cultured in each flask, and each experiment consisted of three independent replicates with 10 culture flasks per replicate.

Shoot formation and plant regeneration. Shoot formation percentage from protocorms 
or PLBs and subsequent plantlet growth status was assessed on $\mathrm{KC}$ or Hyponex N026 media containing $0.1,0.5,1.0$, or 2.0 $\mathrm{mg} \cdot \mathrm{L}^{-1} \mathrm{NAA}, 0.1 \% \mathrm{AC}$, and 50 or $100 \mathrm{~g} \cdot \mathrm{L}^{-1}$ banana homogenate. All experiments consisted of three independent replicates with 10 culture flasks per replicate with 20 protocorms or PLBs in each flask.

Greenhouse acclimatization. The effects of two transplanting methods and two planting media on ex vitro plantlet acclimatization were studied. Plantlets with roots $2 \mathrm{~cm}$ or longer were wrapped in Chilean sphagnum moss and grown attached to fir bark blocks or transplanted into pots with Chilean sphagnum moss or 2:1:1 (v/v) Zhijing stone for orchids (Northridge Enterprise Co., Ltd., Taiwan, China):sieved peat:shattered fir in April. The transplanted plantlets were grown in a greenhouse under no more than $800 \mu \mathrm{mol} \cdot \mathrm{m}^{-2} \cdot \mathrm{s}^{-1}$ natural light. Plantlets were watered at 1- to 2$\mathrm{d}$ intervals. After 1 month of acclimatization, plantlets were fertilized weekly with 150 $\mathrm{mg} \cdot \mathrm{L}^{-1} 20 \mathrm{~N}-20 \mathrm{P}-20 \mathrm{~K}$ fertilizer (Peters Professional 20-20-20; The Scotts Co., Marysville, $\mathrm{OH})$. Average temperatures ranged from 15 to $30{ }^{\circ} \mathrm{C}$ and humidity levels ranged from $70 \%$ to $98 \%$. The percentage plantlet survival was recorded at 30 and $180 \mathrm{~d}$ after transplanting. Each experiment consisted of three independent replicates with 100 plantlets per replicate.

Statistical analysis. All experiments were established in a completely randomized design. Percentage data were converted to relative proportions, arcsine transformed, and then analyzed for significant differences. The data were analyzed with SPSS 11.0 for Windows (Microsoft Corp., Redmond, WA) using oneway analysis of variance, and means were separated using Duncan's multiple range test at $P=0.05$.

\section{Results}

Asymbiotic seed germination and in vitro protocorm growth. TZ testing indicated that seeds were $85.5 \%$ viable. After 4 weeks of culture, seeds germinated on all five tested basal media, although the period required for germination and the germination percentage differed (Table 1). The seed germination percentage on KC media and Orchid Seed Sowing Medium Hyponex N026 were significantly higher than on MS, VW, and half-strength MS media; seed germination percentage on VW and half-strength MS media was significantly higher than on MS. The seed germination period on Hyponex N026 was significantly shorter than on MS or half-strength MS media. Although the seed germination percentage on $\mathrm{KC}$ media was not significantly higher than on Hyponex N026, more protocorms from germinated seed died after subsequent subculture and growth on Hyponex N026; therefore, KC basal media was the most appropriate basal medium for seed germination of $N$. zhejiangensis among all media tested.

$\mathrm{KC}$ medium supplemented with NAA $(0.5$, 1.0 , or $\left.2.0 \mathrm{mg} \cdot \mathrm{L}^{-1}\right)$, with or without $\mathrm{AC}$ and $\mathrm{CW}$, significantly shortened the germination period and increased germination percentage compared with $\mathrm{KC}$ basal medium, except for $\mathrm{KC}$ medium supplemented with $2.0 \mathrm{mg} \cdot \mathrm{L}^{-1}$ NAA, which did not significantly increase germination percentage and $\mathrm{KC}$ medium supplemented with $1.0 \mathrm{mg} \cdot \mathrm{L}^{-1} \mathrm{NAA}, 10 \% \mathrm{CW}$, and $0.2 \% \mathrm{AC}$, which did not significantly shorten the germination period (Table 2). KC medium supplemented with $\mathrm{CW}$ only $(5 \%$, $10 \%$, or $20 \%$ ) significantly increased germination percentage, but only $\mathrm{KC}$ medium supplemented with $10 \% \mathrm{CW}$ significantly shortened the germination period compared with $\mathrm{KC}$ basal medium alone (Table 2). KC medium supplemented with AC only $(0.05 \%$, $0.1 \%$, and $0.2 \%$ ) did not significantly shorten the germination period and increased germination percentage compared with $\mathrm{KC}$ basal medium except for a high concentration of $\mathrm{AC}(0.2 \%)$, which significantly prolonged the germination period (Table 2; Fig. 1B). The KC media tested with combinations of NAA, CW, and $\mathrm{AC}$ significantly increased germination percentage and significantly shortened the germination period except for $\mathrm{KC}$ medium to which $1.0 \mathrm{mg} \cdot \mathrm{L}^{-1} \mathrm{NAA}, 10 \% \mathrm{CW}$, and $0.2 \%$ AC were added, which did not significantly shorten the germination period compared with $\mathrm{KC}$ medium alone. $\mathrm{KC}$ medium containing $1.0 \mathrm{mg} \cdot \mathrm{L}^{-1} \mathrm{NAA}, 10 \% \mathrm{CW}$, and $0.1 \% \mathrm{AC}$ gave the highest percent germination, significantly higher than other media tested except for $\mathrm{KC}$ medium containing $0.5 \mathrm{mg} \cdot \mathrm{L}^{-1} \mathrm{NAA}$, $10 \% \mathrm{CW}$, and $0.1 \% \mathrm{AC}$.
Induction of calli and protocorm-like bodies from protocorms. In induction culture (Table 3), some protocorms formed plantlets with roots, some formed callus or PLBs, whereas others died or did not respond (protocorms formed were maintained indefinitely without further growth). PLBs and callus were easily differentiated, because PLBs were round, single, and easy to peel off from PLB clumps, whereas callus was lump-like and not easy to peel off, although for closely related Cymbidium hybrid orchids, callus is equivalent to miniaturized PLB clusters, which are identical to somatic embryos (Teixeira da Silva and Tanaka, 2006). No callus or PLBs formed, $91.7 \%$ protocorms formed seedlings, whereas only $5.7 \%$ of protocorms died on $\mathrm{KC}$ medium without plant growth regulators and with $10 \% \mathrm{CW}$. Callus could be induced on $\mathrm{KC}$ medium with 0.1 to $2.0 \mathrm{mg} \cdot \mathrm{L}^{-1} 2,4-\mathrm{D}$ or a high concentration of BAP $\left(2.0 \mathrm{mg} \cdot \mathrm{L}^{-1}\right)$. The most suitable medium for callus induction was $\mathrm{KC}$ with $1.0 \mathrm{mg} \cdot \mathrm{L}^{-1} 2,4-\mathrm{D}$, which resulted in $71.3 \%$ callus induction. PLBs were induced on $\mathrm{KC}$ medium with 0.1 to $2.0 \mathrm{mg} \cdot \mathrm{L}^{-1} \mathrm{BAP}$. The most suitable medium for PLB induction was $\mathrm{KC}$ medium with $1.0 \mathrm{mg} \cdot \mathrm{L}^{-1} \mathrm{BAP}$, which resulted in $57.0 \%$ PLB induction. Callus and PLBs were induced synchronously on the same $\mathrm{KC}$ medium with 0.01 to $1.0 \mathrm{mg} \cdot \mathrm{L}^{-1}$ TDZ or with a high concentration $\left(2.0 \mathrm{mg} \cdot \mathrm{L}^{-1}\right)$ of BAP. The higher percentage of protocorm death occurred on $\mathrm{KC}$ medium with a high

Table 1. Effect of basal medium on the period and percentage of Nothodoritis zhejiangensis seed germination. ${ }^{2}$

\begin{tabular}{lcc}
\hline Basal medium & Germination period (days) & Germination (\%) \\
\hline KC & $35.3 \pm 3.2 \mathrm{ab}$ & $40.3 \pm 2.7 \mathrm{a}$ \\
VW & $37.7 \pm 1.5 \mathrm{ab}$ & $29.0 \pm 2.3 \mathrm{~b}$ \\
Half-strength MS & $38.7 \pm 3.0 \mathrm{~b}$ & $24.7 \pm 3.5 \mathrm{~b}$ \\
MS & $40.3 \pm 3.0 \mathrm{~b}$ & $15.7 \pm 2.1 \mathrm{c}$ \\
Hyponex N026 & $30.0 \pm 1.2 \mathrm{a}$ & $46.0 \pm 3.0 \mathrm{a}$ \\
\hline
\end{tabular}

${ }^{2}$ For each treatment, $\approx 100$ seeds were cultured in a 250 -mL culture flask containing $90 \mathrm{~mL}$ of medium. All experiments consisted of three independent replicates with 10 culture flasks per replicate. Values followed by different letters within a column are significantly different at $P<0.05$.

$\mathrm{KC}=$ Knudson's C; VW = Vacin and Went; MS = Murashige and Skoog.

Table 2. Effect of NAA, coconut water, and activated charcoal on period and percentage of Nothodoritis zhejiangensis seed germination. ${ }^{\mathrm{Z}}$

\begin{tabular}{lcccc}
\hline NAA $\left(\mathrm{mg} \cdot \mathrm{L}^{-1}\right)$ & $\begin{array}{c}\text { Coconut } \\
\text { water }(\%)\end{array}$ & $\begin{array}{c}\text { Activated charcoal } \\
(\%)\end{array}$ & $\begin{array}{c}\text { Germination period } \\
(\mathrm{d})\end{array}$ & $\begin{array}{c}\text { Germination } \\
(\%)\end{array}$ \\
\hline 0 & 0 & 0 & $35.3 \pm 3.18 \mathrm{e}$ & $40.3 \pm 2.7 \mathrm{~h}$ \\
0.5 & 0 & 0 & $25.7 \pm 1.8 \mathrm{a}$ & $48.3 \pm 2.7 \mathrm{ef}$ \\
1.0 & 0 & 0 & $28.0 \pm 1.2 \mathrm{abc}$ & $46.0 \pm 1.2 \mathrm{fg}$ \\
2.0 & 0 & 0 & $28.7 \pm 0.9 \mathrm{abc}$ & $43.0 \pm 1.7 \mathrm{fgh}$ \\
0 & 5 & 0 & $36.0 \pm 2.0 \mathrm{e}$ & $49.3 \pm 3.1 \mathrm{de}$ \\
0 & 10 & 0 & $28.7 \pm 1.5 \mathrm{abc}$ & $55.0 \pm 1.2 \mathrm{bcd}$ \\
0 & 20 & 0 & $35.0 \pm 2.7 \mathrm{de}$ & $50.3 \pm 1.5 \mathrm{cde}$ \\
0 & 0 & 0.05 & $33.3 \pm 1.8 \mathrm{cde}$ & $38.7 \pm 2.4 \mathrm{hi}$ \\
0 & 0 & 0.1 & $32.0 \pm 1.2 \mathrm{cde}$ & $41.0 \pm 1.5 \mathrm{ghi}$ \\
0 & 0 & 0.2 & $36.7 \pm 1.2 \mathrm{e}$ & $36.3 \pm 1.8 \mathrm{i}$ \\
0.5 & 10 & 0 & $27.3 \pm 1.5 \mathrm{ab}$ & $58.0 \pm 2.3 \mathrm{~b}$ \\
0.5 & 10 & 0.05 & $29.3 \pm 0.7 \mathrm{abc}$ & $56.0 \pm 2.1 \mathrm{bc}$ \\
0.5 & 10 & 0.1 & $30.0 \pm 2.0 \mathrm{abcd}$ & $60.3 \pm 1.5 \mathrm{ab}$ \\
1.0 & 10 & 0.1 & $27.3 \pm 1.5 \mathrm{ab}$ & $64.7 \pm 1.8 \mathrm{a}$ \\
1.0 & 10 & 0.2 & $32.3 \pm 1.2 \mathrm{bcde}$ & $50.0 \pm 1.7 \mathrm{cde}$ \\
\hline
\end{tabular}

${ }^{2}$ The basal medium was KC. For each treatment, $\approx 100$ seeds were cultured in a $250-\mathrm{mL}$ culture flask containing $90 \mathrm{~mL}$ of medium. All experiments consisted of three independent replicates with 10 culture flasks per replicate. Values followed by different letters within a column are significantly different at $P<0.05$. $\mathrm{NAA}=\alpha$-naphthaleneacetic acid; $\mathrm{KC}=$ Knudson's $\mathrm{C}$. 
concentration of TDZ $\left(1.0 \mathrm{mg} \cdot \mathrm{L}^{-1}\right)$, BAP $(2.0$ $\left.\mathrm{mg} \cdot \mathrm{L}^{-1}\right)$, or $2,4-\mathrm{D}\left(2.0 \mathrm{mg} \cdot \mathrm{L}^{-1}\right)$.

Subculture of callus-induced callus and protocorm-like bodies. The callus proliferation efficiency was tested on $\mathrm{KC}$ medium supplemented with $10 \% \mathrm{CW}$ and $1.0 \mathrm{mg} \cdot \mathrm{L}^{-1}$ 2,4-D from the first to the twelfth subculture (Fig. 2). From the third to the twelfth subculture (Fig. 1C), callus proliferation efficiency was not significantly different but was significantly higher than the first and second subcultures, and the frequency in the second subculture was significantly higher than the first subculture.

Callus from the first to the twelfth subculture readily formed PLBs after transfer to $\mathrm{KC}$ medium supplemented with $1.0 \mathrm{mg} \cdot \mathrm{L}^{-1}$ NAA, $5 \% \mathrm{CW}$, and $0.1 \%$ AC. PLB formation percentage $(82.7 \%, 83.3 \%, 85.0 \%, 84.7 \%$, $83.3 \%, \quad 87.7 \%, \quad 86.3 \%, \quad 85.0 \%, \quad 82.0 \%$, $84.0 \%, 82.7 \%$, and $82.7 \%$ for the 12 subcultures, respectively) was not significantly different between subculture periods on the same media. Of the tested NAA concentrations, $1.0 \mathrm{mg} \cdot \mathrm{L}^{-1}$ was most suitable for PLB formation with a significantly higher PLB formation percentage $(84.0 \%)$ from the tenth subculture compared with other media tested (Table 4). PLBs from callus or protocorms were similar in shape to the protocorms of $N$. zhejiangensis formed after seed germination.

Protocorm-like body proliferation. The PLB proliferation efficiency was 2.2, 2.3, $2.4,2.4,2.3,2.6,2.5,2.6,2.4,2.5,2.3$, and 2.5 for the 12 subcultures, respectively, but was not significantly different between the first and twelfth subcultures at $\approx 50$-d subculture intervals on $\mathrm{KC}$ medium supplemented with $10 \% \mathrm{CW}$ and $1.0 \mathrm{mg} \cdot \mathrm{L}^{-1}$ BAP (Fig. 1D).

Shoot formation and plant regeneration. Hyponex N026 medium supplemented with $0.1 \% \mathrm{AC}$ and $1.0 \mathrm{mg} \cdot \mathrm{L}^{-1} \mathrm{NAA}$ with or without $50 \mathrm{mg} \cdot \mathrm{L}^{-1}$ banana homogenate was most suitable for plantlet formation among the tested media, and $89.3 \%$ or $95.3 \%$ of PLBs from the tenth subculture formed plantlets in these media (Table 5). Plantlet formation efficiency was $88.3 \%, 89.7 \%, 90.0 \%, 93.7 \%, 92.0 \%$, $94.7 \%, 89.7 \%, 88.7 \%, 92.7 \%, 95.3 \%, 96.0 \%$, and $95.0 \%$ for the 12 subcultures, respectively, but was not significantly different from the PLBs of the first to twelfth subcultures. Some PLBs $(6.0 \%, 11.3 \%, 6.3 \%$, respectively) died on Hyponex N026 media supplemented with 0.5 or $1.0 \mathrm{mg} \cdot \mathrm{L}^{-1} \mathrm{NAA}$ and $100 \mathrm{~g} \cdot \mathrm{L}^{-1}$ banana homogenate or with $2.0 \mathrm{mg} \cdot \mathrm{L}^{-1} \mathrm{NAA}$ without banana homogenate. Hyponex N026 medium supplemented with 0.5 or $1.0 \mathrm{mg} \cdot \mathrm{L}^{-1} \mathrm{NAA}$ and $50 \mathrm{~g} \cdot \mathrm{L}^{-1}$ banana homogenate favored plantlet growth most (Table 5).

Greenhouse acclimatization. Plantlets grew vigorously after $30 \mathrm{~d}$ transplanting with high plantlet survival percentages that were not significantly different between media. After growth in a greenhouse for $180 \mathrm{~d}$, plantlet survival rate on fir bark blocks was significantly higher than on Chilean sphagnum moss or on the sand/peat/fir bark mixture (Table 6). On all three media, plantlet survival percentage was significantly higher at $30 \mathrm{~d}$ transplanting compared with 180 d. Approximately 5000
Table 3. Effect of TDZ, BAP, and 2,4-D on induction of callus and PLB from Nothodoritis zhejiangensis protocorms. $^{z}$

\begin{tabular}{|c|c|c|c|c|c|}
\hline $\begin{array}{l}\text { Plant growth } \\
\text { regulators }\left(\mathrm{mg} \cdot \mathrm{L}^{-1}\right) \\
\text { TDZ BAP } 2,4-\mathrm{D}\end{array}$ & $\begin{array}{l}\text { Seedling } \\
\text { formation } \\
\quad(\%)\end{array}$ & $\begin{array}{l}\text { Callus } \\
\text { induction } \\
(\%)\end{array}$ & $\begin{array}{c}\text { PLB } \\
\text { induction } \\
(\%)\end{array}$ & $\begin{array}{l}\text { Protocorm with } \\
\text { no response } \\
(\%)\end{array}$ & $\begin{array}{l}\text { Protocorm } \\
\text { death } \\
(\%)\end{array}$ \\
\hline 000 & $91.7 \pm 0.9 \mathrm{a}$ & $0 \mathrm{~g}$ & $0 \mathrm{f}$ & $2.7 \pm 0.3 \mathrm{a}$ & $5.7 \pm 0.7 \mathrm{f}$ \\
\hline 0.0100 & $82.3 \pm 1.5 b$ & $1.0 \pm 0.6 \mathrm{~g}$ & $4.7 \pm 0.3 \mathrm{e}$ & $4.7 \pm 0.7 \mathrm{a}$ & $7.3 \pm 0.6 \mathrm{ef}$ \\
\hline 0.100 & $57.7 \pm 2.0 \mathrm{~d}$ & $7.0 \pm 0.6 \mathrm{f}$ & $20.3 \pm 0.9 \mathrm{~d}$ & $0 \mathrm{~b}$ & $15.0 \pm 1.5 \mathrm{c}$ \\
\hline 0.500 & $33.0 \pm 1.5 \mathrm{f}$ & $9.7 \pm 0.3 \mathrm{e}$ & $36.3 \pm 0.9 \mathrm{c}$ & $0 \mathrm{~b}$ & $21.0 \pm 1.5 \mathrm{~b}$ \\
\hline 1.000 & $20.3 \pm 2.0 \mathrm{~g}$ & $9.7 \pm 0.9 \mathrm{e}$ & $38.0 \pm 0.6 \mathrm{c}$ & $0 \mathrm{~b}$ & $32.0 \pm 1.2 \mathrm{a}$ \\
\hline 00.10 & $86.3 \pm 2.3 \mathrm{ab}$ & $0 \mathrm{~g}$ & $5.0 \pm 0.6 \mathrm{e}$ & $4.7 \pm 0.6 \mathrm{a}$ & $4.0 \pm 1.0 \mathrm{f}$ \\
\hline 00.50 & $75.3 \pm 2.6 \mathrm{c}$ & $0 \mathrm{~g}$ & $19.7 \pm 1.5 \mathrm{~d}$ & $0 \mathrm{~b}$ & $5.0 \pm 1.2 \mathrm{f}$ \\
\hline 01.00 & $31.3 \pm 1.5 \mathrm{f}$ & $0 \mathrm{~g}$ & $57.0 \pm 1.7 \mathrm{a}$ & $0 \mathrm{~b}$ & $14.0 \pm 2.7 \mathrm{~cd}$ \\
\hline 02.00 & $15.7 \pm 3.0 \mathrm{~g}$ & $5.3 \pm 0.9 \mathrm{f}$ & $54.0 \pm 1.5 \mathrm{~b}$ & $0 \mathrm{~b}$ & $25.0 \pm 1.2 \mathrm{a}$ \\
\hline $\begin{array}{lllll}0 & 0 & 0.1\end{array}$ & $60.7 \pm 2.4 \mathrm{~d}$ & $30.3 \pm 0.9 \mathrm{~d}$ & $0 \mathrm{f}$ & $3.7 \pm 0.7 \mathrm{a}$ & $5.7 \pm 1.2 \mathrm{f}$ \\
\hline $\begin{array}{llll}0 & 0 & 0.5\end{array}$ & $39.3 \pm 1.8 \mathrm{e}$ & $50.0 \pm 0.6 \mathrm{c}$ & $0 \mathrm{f}$ & $0 \mathrm{~b}$ & $10.7 \pm 1.2 \mathrm{de}$ \\
\hline $\begin{array}{llll}0 & 0 & 1.0\end{array}$ & $15.7 \pm 2.33 \mathrm{~g}$ & $71.3 \pm 1.2 \mathrm{a}$ & $0 \mathrm{f}$ & $0 \mathrm{~b}$ & $13.0 \pm 1.5 b$ \\
\hline $\begin{array}{llllll}0 & 0 & 2.0\end{array}$ & $4.7 \pm 0.9 \mathrm{~h}$ & $62.0 \pm 1.2 \mathrm{~b}$ & $0 \mathrm{f}$ & $0 \mathrm{~b}$ & $33.3 \pm 1.7 \mathrm{a}$ \\
\hline
\end{tabular}

${ }^{\mathrm{z}}$ The basal medium was KC with $10 \%$ coconut water. All experiments consisted of three independent replicates with 10 culture flasks per replicate and 20 protocorms per flask. Values followed by different letters within a column are significantly different at $P<0.05$.

$\mathrm{TDZ}=$ thidiazuron; $\mathrm{BAP}=6$-benzylaminopurine; $2,4-\mathrm{D}=$ 2,4-dichlorophenoxyacetic acid; PLB = protocorm-like body; $\mathrm{KC}=$ Knudson's C.

plantlets from seed germination and plant regeneration of a mature seed capsule were produced and planted successfully within 2 years. Seedlings or plantlets were successfully acclimatized to greenhouse conditions and can be used for ornamental, reintroduction, and conservation purposes.

\section{Discussion}

The general regeneration procedure of orchid regeneration through in vitro seed germination is protocorm formation from seed, seedling development in vitro, and acclimatization of seedlings (Kauth et al., 2006, 2008; Shiau et al., 2005), which is effective for in vitro conservation of orchids (Dutra et al., 2008). Although in vitro propagation has long been associated with orchid propagation (Arditti, 1967, 1982, 2008), asymbiotic seed germination and tissue culture of Nothodoritis zhejiangensis have never been reported. As part of a conservation plan for this monophyletic species, an efficient propagation system is necessary. In this study, an effective micropropagation system was established through the induction of callus and PLBs and their successful subculture and proliferation from protocorms. This resulted in an efficient large-scale propagation of this endangered orchid with 5000 plantlets being propagated within 2 years.

Seed germination and seedling development were prominently affected by the choice of medium. Some orchid species prefer a low salt and nitrogen medium for seed germination (Arditti and Ernst, 1984; Fast, 1982; Van Waes and Debergh, 1986) and PLB formation (Teixeira da Silva et al., 2005). N. zhejiangensis showed significantly lower seed germination on MS than on half-strength MS medium possibly because of the high salt concentration of MS. However, low salt content was not the only factor affecting seed germination of $N$. zhejiangensis, because $\mathrm{KC}$, half-strength MS, and VW media all contained a low salt concentration, although seed germination

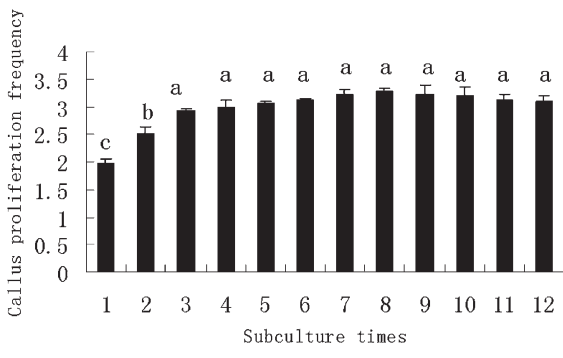

Fig. 2. Effect of subculture period of Nothodoritis zhejiangensis on callus proliferation on Knudson's C medium supplemented with $10 \%$ coconut water and $1.0 \mathrm{mg} \cdot \mathrm{L}^{-1}$ 2,4-dichlorophenoxyacetic acid shown at 50-d intervals. Different letters within a column are significantly different at $P<$ 0.05 .

percentage was significantly higher on $\mathrm{KC}$ medium than on half-strength MS and VW media.

Orchid seed germination and protocorm and/or PLB development is stimulated by organic amendments (Chu and Mudge, 1994; DeMarie et al., 1991; Harvais, 1973; Teixeira da Silva et al., 2006). CW was supplemented in the germination medium because of its beneficial effect on seed germination, which had been reported for orchids like Bletia urbana (Rubluo et al., 1989), Cattleya (Kerbuay and Handro, 1981), and Cymbidium (Teixeira da Silva et al., 2005, 2006). CW contains amino acids, vitamins, sugar, and plant growth regulators such as cytokinin (Laurain et al., 1993) as well as various inorganic ions such as phosphorus, magnesium, potassium, and sodium (Raghavan, 1977), which are beneficial for orchid seed germination. Hence, the responses of in vitro asymbiotic germination of $N$. zhejiangensis to $\mathrm{CW}$ were investigated and the result was consistent. In addition, Phalaenopsis callus induction and somatic embryogenesis was stimulated by $20 \% \mathrm{CW}$ (Ishii et al., 1998). CW was also essential for direct embryogenesis (Laurain et al., 1993) and enhancement of axillary shoot growth 
Table 4. Effect of NAA concentration on PLB formation from callus of the tenth subculture of Nothodoritis zhejiangensis. ${ }^{\mathrm{z}}$

\begin{tabular}{lccc}
\hline $\begin{array}{l}\text { NAA } \\
\left(\mathrm{mg} \cdot \mathrm{L}^{-1}\right)\end{array}$ & $\begin{array}{c}\text { Callus proliferation } \\
(\%)\end{array}$ & $\begin{array}{c}\text { Callus and PLB } \\
\text { proliferation }(\%)\end{array}$ & $\begin{array}{c}\text { PLB formation } \\
(\%)\end{array}$ \\
\hline 0 & $30.7 \pm 1.7 \mathrm{a}$ & $49.3 \pm 2.3 \mathrm{a}$ & $20.0 \pm 0.6 \mathrm{e}$ \\
0.1 & $26.3 \pm 1.5 \mathrm{a}$ & $44.3 \pm 2.3 \mathrm{a}$ & $29.3 \pm 2.3 \mathrm{~d}$ \\
0.5 & $15.0 \pm 1.7 \mathrm{~b}$ & $30.0 \pm 2.5 \mathrm{~b}$ & $55.0 \pm 1.2 \mathrm{c}$ \\
1.0 & $6.0 \pm 1.0 \mathrm{c}$ & $10.0 \pm 1.5 \mathrm{c}$ & $84.0 \pm 2.1 \mathrm{a}$ \\
2.0 & $11.3 \pm 0.9 \mathrm{~b}$ & $15.0 \pm 1.5 \mathrm{c}$ & $73.7 \pm 1.5 \mathrm{~b}$ \\
\hline
\end{tabular}

${ }^{\mathrm{z}}$ The basal medium was $\mathrm{KC}$ with $5 \%$ coconut water and $0.1 \%$ activated charcoal. All experiments consisted of three independent replicates with 10 culture flasks per replicate and with 20 callus clumps per flask. Values followed by different letters within a column are significantly different at $P<0.05$.

$\mathrm{NAA}=\alpha$-naphthaleneacetic acid; PLB = protocorm-like body; $\mathrm{KC}=$ Knudson's $\mathrm{C}$.

Table 5. Effect of NAA and banana homogenate concentration on plantlet formation from PLBs derived from the tenth subculture of Nothodoritis zhejiangensis. ${ }^{2}$

\begin{tabular}{lccccc}
\hline $\begin{array}{l}\text { NAA } \\
\left(\mathrm{mg} \cdot \mathrm{L}^{-1}\right)\end{array}$ & $\begin{array}{c}\text { Banana homogenate } \\
\left(\mathrm{g} \cdot \mathrm{L}^{-1}\right)\end{array}$ & $\begin{array}{c}\text { PLB proliferation } \\
(\%)\end{array}$ & $\begin{array}{c}\text { Plantlet formation } \\
(\%)\end{array}$ & $\begin{array}{c}\text { Necrosis } \\
(\%)\end{array}$ & Growth status \\
\hline 0 & 0 & $25.7 \pm 3.5 \mathrm{a}$ & $74.3 \pm 3.5 \mathrm{c}$ & $0 \mathrm{c}$ & ++ \\
0.5 & 0 & $20.7 \pm 2.3 \mathrm{ab}$ & $79.3 \pm 2.3 \mathrm{c}$ & $0 \mathrm{c}$ & ++ \\
1.0 & 0 & $10.7 \pm 1.2 \mathrm{c}$ & $89.3 \pm 2.9 \mathrm{ab}$ & $0 \mathrm{c}$ & ++ \\
2.0 & 0 & $20.0 \pm 1.2 \mathrm{ab}$ & $73.7 \pm 2.2 \mathrm{c}$ & $6.3 \pm 1.2 \mathrm{~b}$ & + \\
0.5 & 50 & $22.0 \pm 1.2 \mathrm{ab}$ & $78.0 \pm 1.7 \mathrm{c}$ & $0 \mathrm{c}$ & +++ \\
0.5 & 100 & $17.7 \pm 0.9 \mathrm{~b}$ & $76.3 \pm 0.7 \mathrm{c}$ & $6.0 \pm 0.6 \mathrm{~b}$ & ++ \\
1.0 & 50 & $4.7 \pm 0.9 \mathrm{~d}$ & $95.3 \pm 0.9 \mathrm{a}$ & $0 \mathrm{c}$ & +++ \\
1.0 & 100 & $3.0 \pm 1.5 \mathrm{~d}$ & $85.7 \pm 2.3 \mathrm{~b}$ & $11.3 \pm 0.9 \mathrm{a}$ & + \\
\hline
\end{tabular}

${ }^{z_{+},++,+++=}$poor, normal, and good growth, respectively. All experiments consisted of three independent replicates with 10 culture flasks per replicate and 20 PLBs per flask. Values followed by different letters within a column are significantly different at $P<0.05$. The basal medium was Hyponex N026 containing $0.1 \%$ activated charcoal.

$\mathrm{NAA}=\alpha$-naphthaleneacetic acid; PLBs $=$ protocorm-like bodies.

Table 6. Survival rate of Nothodoritis zhejiangensis seedlings grown on three different supporting mixtures after 30 and $180 \mathrm{~d}^{\mathrm{z}}$

\begin{tabular}{lcc}
\hline Transplanting conditions & $\begin{array}{c}\text { Survival rate after } 30 \mathrm{~d} \text { of } \\
\text { transplanting }(\%)\end{array}$ & $\begin{array}{c}\text { Survival rate after } 180 \mathrm{~d} \text { of } \\
\text { transplanting }(\%)\end{array}$ \\
\hline Fixed on fir bark blocks & $90.0 \pm 2.9 \mathrm{aA}$ & $69.3 \pm 2.2 \mathrm{aB}$ \\
Chilean sphagnum moss & $92.3 \pm 1.5 \mathrm{aA}$ & $56.0 \pm 2.1 \mathrm{bB}$ \\
Mixture media $^{\mathrm{y}}$ & $85.7 \pm 4.0 \mathrm{aA}$ & $45.3 \pm 3.2 \mathrm{cB}$ \\
\hline
\end{tabular}

${ }^{2}$ Values followed by different lower-case letters within a column or by different capital letters within a row are significantly different at $P<0.05$. Each experiment consisted of three independent replicates with 100 plantlets per replicate.

${ }^{\mathrm{y}}$ Contains 2:1:1 (v/v) Zhijing stone for orchids:sieved peat:shattered fir bark.

(Boase et al., 1993). Therefore, CW was also used to induce and proliferate $N$. zhejiangensis callus and PLBs.

In the present report, callus and PLBs were induced from seed-derived protocorms, which could be subcultured and maintained on $\mathrm{KC}$ medium containing 2,4-D or BAP. Callus was totipotent by being able to regenerate plantlets through PLBs as an intermediate step. Callus and PLBs were subcultured $\approx 12$ times over a 2-year period without losing their ability to regenerate plantlets. This protocol can thus be used for large-scale, continual propagation of this endangered orchid. In our study, 2,4-D, $\mathrm{BAP}$, or TDZ played different roles in callus and PLB induction. 2,4-D alone was suitable for callus induction, BAP alone was more beneficial for PLB formation, whereas TDZ was not suitable for callus or PLB induction when used alone.

PLB formation from callus was significantly affected by NAA concentrations in our study; similar results have also been reported for a Maudiae-type slipper orchid (Hong et al., 2008). Banana homogenate was used in medium to facilitate plantlet in vitro growth of
Renanthara imschootiana (Seeni and Latha, 1992); in our study, Hyponex N026 media supplemented with $50 \mathrm{~g} \bullet \mathrm{L}^{-1}$ banana homogenate favored plantlet in vitro growth more than with or without $100 \mathrm{~g} \cdot \mathrm{L}^{-1}$ banana homogenate.

$N$. zhejiangensis is only found growing as an epiphyte on the trunks of trees, and to our knowledge, there have been no reports of artificial planting of this endangered Chinese orchid. Plantlets exhibited vigorous growth with high survival rates from April to July; some plantlets died from August to September possibly as a result of inclement weather in greenhouse conditions in South China. However, when plantlets were planted on fir bark blocks, the survival rate was significantly higher than in pots with Chilean sphagnum moss or a sand/peat/fir bark mixture after $180 \mathrm{~d}$ transplanting (Table 6). A similar environment as that found in nature is likely to be suitable for growth of $N$. zhejiangensis plantlets, even in greenhouse conditions. How to increase survival rates of $N$. zhejiangensis plantlets needs further research.

In conclusion, this study reports a procedure for asymbiotic germination, in vitro seedling culture, and regeneration system through PLBs and callus as well as greenhouse acclimatization of $N$. zhejiangensis that can be used for conservation and commercial production. Conservation of endangered of threatened orchid species can benefit from germination and acclimatization protocols that focus on propagating orchid seedlings for reintroduction or maintaining protocorms and seedlings in vitro. Callus and PLBs were incubated 12 times over 2 years and did not lose their competence to regenerate plantlets, enhancing the commerce importance for the mass production of $N$. zhejiangensis. Whether that callus or PLBs can be used for short-term or long-term germplasm conservation depends on further studies of genetic stability.

\section{Literature Cited}

Arditti, J. 1967. Factors affecting the germination of orchid seeds. Bot. Rev. 33:1-97.

Arditti, J. 1982. Orchid biology: Reviews and perspective II, p. 243-370. Cornell Univ. Press, Ithaca, NY.

Arditti, J. 2008. Micropropagation of orchids. Vols. I-II. 2nd Ed. Blackwell Publishing Ltd., New York, NY.

Arditti, J. and R. Ernst. 1984. Physiology of germinating orchid seeds, p. 177-222. In: Arditti, J. (ed.). Orchid biology: Reviews and perspectives III. Cornell Univ. Press, Ithaca, New York.

Boase, M.R., S. Wright, and P.L. McLeay. 1993. Coconut water enhancement of axillary shoots growth of in vitro kiwifruit. N. Z. J. Crop Hort. Sci. 21:171-176.

Chen, J.T. and W.C. Chang. 2006. Direct somatic embryogenesis and plant regeneration from leaf explants of Phalaenopsis amabilis. Biol. Plant. 6:169-173.

Christenson, E.A. 2001. Phalaenopsis-A monograph. Timber Press, Portland, OR. pp. 44-45.

Chu, C.C. and K.W. Mudge. 1994. Effects of prechilling and liquid suspension culture on seed germination of the Yellow Lady's slipper orchid, Cypripedium calceoclus var. pubescens. Lindleyana 9:153-159.

DeMarie, E., M. Weimer, and W. Mudge. 1991. In vitro germination and development of Showy Lady' Slipper orchid (Cypripedium reginae Walt.) seeds. HortScience 26:272.

Dutra, D., T.R. Johnso, P.J. Kauth, S.L. Stewart, M.E. Kane, and L. Richardson. 2008. Asymbiotic seed germination, in vitro seedling development, and greenhouse acclimatization of the threatened terrestrial orchid Bletia purpurea. Plant Cell Tissue Organ Cult. 94:11-121.

Fast, G. 1982. European terrestrial orchids. Symbiotic and asymbiotic methods, p. 203-293. In: Arditti, J. (ed.). Orchid biology: Reviews and perspectives, I. Cornell Univ. Press, Ithaca, NY.

Fu, L.K. and T. Hong. 2002. Higher plant of China. Qingdao Publishing House, Qingdao, China. 722.

Harvais, G. 1973. Growth requirements and development of Cypripedium reginae in axenic culture. Can. J. Bot. 51:327-332.

Hong, P.L., J.T. Chen, and W.C. Chang. 2008. Plant regeneration via protocorm-like body formation and shoot multiplication from seedderived callus of a maudiae type slipper orchid. Acta Physiol. Plant. 30:755-759.

Ishii, Y., T. Takamura, and M. Goi. 1998. Callus induction and somatic embryogenesis of Phalaenopsis. Plant Cell Rep. 17:446-450.

Kauth, P.J., D. Dutra, T.R. Johnson, S.L. Stewart, M.E. Kane, and W. Vendrame. 2008. Techniques 
and applications of in vitro orchid seed germination, p. 375-391. In: Teixeira da Silva, J.A (ed.). Floriculture, ornamental and plant biotechnology: Advances and topical issues. 1st Ed., Vol V. Global Science Books, Isleworth, UK.

Kauth, P.J., W.A. Vendrame, and M.E. Kane. 2006. In vitro seed culture and seedling development of Calopogon tuberosus. Plant Cell Tissue Organ Cult. 85(1):91-102.

Kerbuay, G.B. and W. Handro. 1981. Cultures of orchid embryo in liquid medium. Orchid Rev. 89:316-318.

Knudson, L. 1946. A new nutrient solution for the germination of orchid seeds. Amer. Orchid Soc. Bull. 15:214-217.

Lakon, G. 1949. The topographical tetrazolium method for determining the germination capacity of seeds. Plant Physiol. 24:389-394.

Laurain, D., J.C. Chenieux, and J. TremouillauxGuiller. 1993. Direct embryogenesis from female haploid protoplasts of Ginkgo balboa L., a medicinal woody species. Plant Cell Rep. 12:656-660.

Murashige, T. and F. Skoog. 1962. A revised medium for rapid growth and bio-assays with tobacco tissue cultures. Physiol. Plant. 15:473-497.

Qiu, L.W., J. Wang, L.H. Xiao, and H.D. Zhen. 2009. A highly effective propagation technology for Phalaenopsis. Guangxi Agr. Sci. 40(12): 1523-1525.
Raghavan, V. 1977. Diets and culture media for plant embryos, p. 361-413. In: Rechcigl, M.J. (ed.). CRC handbook series in nutrition and food. Taylor \& Francis Publisher, London, UK.

Rubluo, A., V. Chavez, and A. Martinez. 1989. In vitro seed germination and reintroduction of Bletia urbana (Orchidaceae) in its natural habitats. Lindleyana 4(2):68-73.

Seeni, S. and P.G. Latha. 1992. Foliar regeneration of the endangered Red vanda, Renanthera imschootiana Rolfe. Plant Cell Tissue Organ Cult. 29:167-172.

Shi, C.K., X.J. Liu, and X.G. Sunday. 2008. Four taxa of Orchidaceae newly recorded from Gansu Province. Journal of Gansu Agri. Univ. 43:130-132.

Shiau, Y.L., S.M. Nalawade, C.N. Hsai, and H.S. Tsay. 2005. Propagation of Haemaria discolor via in vitro seed germination. Biol. Plant. 49(3): 341-346.

Teixeira da Silva, J.A., M.T. Chan, Sanjaya, M.L. Chai, and M. Tanaka. 2006. Priming abiotic factors for optimal hybrid Cymbidium (Orchidaceae) PLB and callus induction, plantlet formation, and their subsequent cytogenetic stability analysis. Sci. Hort. 109(4):368-378.

Teixeira da Silva, J.A. and M. Tanaka. 2006. Embryogenic callus, PLB and TCL paths to regeneration in hybrid Cymbidium (Orchidaceae). J. Plant Growth Regul. 25(3):203-210.
Teixeira da Silva, J.A., T. Yam, S. Fukai, N. Nayak, and M. Tanaka. 2005. Establishment of optimum nutrient media for in vitro propagation of Cymbidium Sw. (Orchidaceae) using protocorm-like body segments. Propagation Ornamental Plants 5(3):129-136.

Tokuhara, K. and M. Mii. 1993. Micropropagation of Phalaenopsis and. Doritaenopsis by culturing shoot tips of flower stalk buds. Plant Cell Rep. 13:7-11.

Tsi, Z.H. 1989. Nothodoritis Tsi-A new genus of Orchidaceae from China. Acta Phytotax. Sin. 27(1):58-61.

Tsi, Z.H. 1999. Flora Reipublicae popularis sinicae, Science Press, Beijing. Tomus 19:278-279.

Vacin, E.F. and F.W. Went. 1949. Some pH changes in nutrient solutions. Bot. Gaz. 110:605-613.

Van Waes, J.M. and P.C. Debergh. 1986. In vitro germination of some western European orchids. Physiol. Plant. 67:253-261.

Wu, C.H., X.L. Ye, and C.Y. Liang. 2005. In vitro seed germination in Doritis pulcherrima. Guihaia 25(2):149-151.

Wu, Z.Y., P.H. Raven, and D.Y. Hong (eds.). 2009. Flora of China. Vol. 25 (Orchidaceae). Science Press, Beijing, and Missouri Botanical Garden Press, St. Louis, MO. 446.

Zeng, S.J. 2009. Nothodoritis zhejiangensis Z. H. Tsi-A rare and endangered epiphytic orchid in China. Flower 8:29. 